\title{
EFFECT OF BIOCHAR WITH AND WITHOUT PHOSPHORUS FERTILIZERS ON PHOSPHORUS FRACTIONS, WHEAT YIELD AND MICROBAL BIOMASS CARBON IN ALKALINE SOIL
}

\author{
E. Mahmoud ${ }^{(1)}$, M. Ibrahim ${ }^{(1)}$, Lamyaa A. Abd El-Rahman ${ }^{(2)}$ \\ and Asmaa Khader ${ }^{(2)}$ \\ (1) Department of soil and water science, Faculty of agriculture, Tanta University, Egypt \\ (2) Soil, Water and Environment Res. Inst., Agric. Res. Center, Giza. Egypt \\ * Corresponding author email: esawy.rezk@agr.tanta.edu.eg
}

Received: Aug. 9, 2018

Accepted: Aug. 16, 2018

\begin{abstract}
The present work was carried out to investigate the effect of biochar and phosphorus fertilizer application, on phosphorus fractions, soil microbial biomass carbon in alkaline soil during two seasons for wheat (Triticum aestivum L. cv. Gemmiza) in field experiments. Phosphorus was added at $0 \%, 50 \%, 100 \%$ and $150 \% P$ of recommended $P$ fertilizers, with or without biochar at a rate of $10 t h^{-1}$ arranged in a randomized complete block design with three replicates. Results showed that the wheat grain yield increased by 56 to $69 \%$ in plots treated with the interaction of biochar and $P$ mineral during the 2015 and 2016 growing seasons. Sequential extraction of the biochartreated with $P$ revealed that $\mathrm{HCl}-P$ decreased, whereas others fractions increased with increasing $P$ rate. The results of this study reveal that the co- application of biochar with inorganic $P$ can be a promising strategy to improve soil productivity and soil quality in alkaline soil.
\end{abstract}

Key words: Phosphorus fractions; Biochar; Soil quality; Vertisol; Wheat yield.

\section{INTRODUCTION}

In arid and semi-arid regions, soils are low in organic matter $(<1 \%)$ and plant available nutrients. Although the total amount of $P$ in the soil may be high, it is not meeting the nutritional requirements of crops (Mohamed et al. 2000), because in the soil more than $80 \%$ of the $P$ becomes immobile and unavailable for plant uptake because of adsorption, precipitation, or converted to the organic form (Holford 1997). Phosphorus (P) is one of the main growing plants, limiting nutrients although it is abundant in soils in both inorganic and organic forms. Use of mineral $\mathbf{P}$ fertilizers and biochar can be a promising strategy to improve soil fertility and increase the efficiency of the use of $P$ fertilizers in alkaline soils (Gunes et al. 2014). Agricultural waste is a great importance to soil quality by recycling of these as biochar (Widowati \& Asnah 2014). Biochar is become as a simple technology that can provide multiple environmental benefits when added to soil, including long-term carbon sequestration (C) and increased $P$ use efficiency in soil (Woolf et al. 2010). (Mahmoud et al. 2017) found that availability of phosphate in soils increased with biochar applied as soil amendments. Several studies have explained that the biochars applied in the soil could enhance $P$ availability in soils and decrease $P$ fixation (Novak et al. 2009; Silber et al. 2010; Chintala et al. 2014). Moreover, the biochar application could decrease $\mathbf{P}$ loss of applied $\mathbf{P}$ fertilizers during the leaching, as a result, reducing the pollution risk in the water and soils (Laird et al. 2010 \& Kumari et al. 2014). Biochar has the potential to 
increase $P$ availability by nutrient inputs, increasing CEC, or altering soil pH (Enders et al. 2012; Jones et al. 2012 \& Yuan et al. 2011).

$P$ fraction is important to assess the $P$ status of soils and to study the chemistry of soils that influence environmental and soil quality. In general, the $\mathbf{P}$ distribution in the soils examined that after Headley fraction; more than $40 \%$ of $P$ remained in the residual fraction in all soils (Turner et al. 2005; Condron \& Newman 2011). Inorganic $P$ in all fractions increased significantly by $\mathbf{P}$ fertilization (Solomon \& Lehman 2000). Biochar with fertilizers significantly increased Olsen $P$ and labile $P$ concentrations (Chathurika et al. 2016).

Wheat is one of the main important crops for global food security. Cultivated cereal in the world is more than 220 million ha to produce about 670 million tons. In Egypt, wheat is one of the main and strategic crops that have caused a complex problem, especially the gap between high production and consumption. Wheat production in Egypt reached 9.46 million tons in 2012 (covers $40 \%$ of our needs), produced from an area of 1.419 million ha (CAPMAS 2014). The aim of this study was to investigate the effects of the co-application of $P$ fertilizers and a biochar on soil $P$ fractionation and wheat yield over two growth seasons in alkaline soil.

\section{MATERIALS AND METHODS Biochar production}

Citrus trees pruning biochar used in this study is locally produced using a batch pyrolysis facility at a final temperature $\left(500^{\circ} \mathrm{C}\right)$ with a retention time of $2 \mathrm{~h}$. Biochar samples were ground and sieved $<0.5 \mathrm{~mm}$, prior to use and characterization. The main characteristics of the biochar are $\mathrm{pH}$ (8.09), OC (46.85\%) and available nutrients $\mathrm{N}(1.4 \%), \mathrm{P}(0.92 \%)$ and $\mathrm{K}$ $(1.42 \%)$, as described in (Table 1 ).

\section{Field experiment}

A field experiment was carried out during the two winter seasons of 2015/2016 and 2016/2017 at Experimental Farm of El-Gemmiza Agric.Res-Station, Agric. Res-center, El-Gharbia governorate, Egypt $\left(30^{\circ} 43 \mathrm{~N}-31^{\circ} 07\right)$ to evaluate the effect of biochar along with different $\mathbf{P}$ fertilizer rates on phosphorus fractionation, microbial biomass carbon and wheat yield (Triticum aestivum). Soil type was a Vertic Torrifuvents (Gad \& Ali 2011). The soil temperature regime of the studied area could be defined as Thermic and soil moisture regimes as Torric, main soil characteristics were shown in (Table 2). Treatments consisted of a factorial combination of four phosphate fertilizer levels (0\% P, 50\% P, 100\% P and $150 \% P$ of recommended $P$ fertilizers) and two biochar levels $\left(0.0\right.$ and $\left.10 \mathrm{t} \mathrm{h}^{-1}\right)$ arranged in a randomized complete block design with three replicates. The field was plowed and mixed of biochar at $10 \mathrm{t} \mathrm{h}^{-1}$. Plot area was $14 \mathrm{~m}^{2}(4 \mathrm{~m} \times 3.5 \mathrm{~m})$. Basic application of $\mathrm{N}$ and $\mathrm{K}$ were applied to all plots i.e. $178 \mathrm{~kg} \mathrm{~N} \mathrm{~h}^{-1}$ and $57.12 \mathrm{~kg} \mathrm{~K}_{2} \mathrm{O}$ $\mathrm{h}^{-1}$ in the forms of urea $(46 \% \mathrm{~N})$ and potassium sulphate $\left(48 \% \quad \mathrm{~K}_{2} \mathrm{O}\right)$, respectively. The other usual agronomic processes of wheat plants (variety of Gememiza 9) were practiced. Wheat seeds were sown at the second week of November by using $142.8 \mathrm{~kg} \mathrm{ha}^{-1}$ grain rate. Wheat plants were harvested after 190 days of sowing when the grains were reopened. After harvesting, straw and grain weight was recorded by using a weighting balance. Soil samples at a depth of $0-30 \mathrm{~cm}$ and $30-60 \mathrm{~cm}$ was taken after wheat harvesting from each plot and analyzed for the selected soil chemical properties. The soil samples collected were air-dried and crushed to pass 
through a $2 \mathrm{~mm}$ sieve for chemical properties. Grain yield was recorded by using weighing balance after harvesting;

Table (1): The main characteristics of biochar.

\begin{tabular}{|c|c|c|c|c|c|c|c|c|c|c|}
\hline Parameters & $\begin{array}{c}\mathrm{pH} \\
(1: 10)\end{array}$ & $\begin{array}{c}\text { EC } \\
\text { ds m-1 } \\
(1: 10)\end{array}$ & $\begin{array}{l}\text { OC } \\
\%\end{array}$ & $\begin{array}{l}\text { CEC } \\
\text { Cmole kg- } \\
1\end{array}$ & $\begin{array}{l}\mathbf{N} \\
\%\end{array}$ & $\begin{array}{l}\mathbf{P} \\
\%\end{array}$ & $\begin{array}{l}\mathbf{K} \\
\%\end{array}$ & $\begin{array}{l}\mathbf{C a} \\
\%\end{array}$ & $\begin{array}{l}\mathbf{M g} \\
\%\end{array}$ & $\mathbf{C} / \mathbf{N}$ \\
\hline Values & 8.09 & 0.52 & 46.8 & 30.31 & 1.4 & 0.92 & 1.42 & 1.5 & 2.7 & 33.40 \\
\hline
\end{tabular}

Table (2): The main properties of the soil.

\begin{tabular}{|c|c|c|c|c|c|}
\hline \multirow{3}{*}{ Soil properties } & \multirow[t]{3}{*}{ Unit } & \multicolumn{2}{|c|}{ Season 2015} & \multicolumn{2}{|c|}{ Season 2016} \\
\hline & & \multicolumn{4}{|c|}{ Soil depth, cm } \\
\hline & & $0-30$ & $30-60$ & $0-30$ & $30-60$ \\
\hline \multicolumn{6}{|l|}{ Particle size distribution } \\
\hline Sand & $\%$ & 16.42 & 16.71 & 16.31 & 16.48 \\
\hline Silt & $\%$ & 25.77 & 27.37 & 30.12 & 27.75 \\
\hline Clay & $\%$ & 57.81 & 55.39 & 53.57 & 55.57 \\
\hline Texture & & clay & clay & clay & clay \\
\hline bulk density & $\mathrm{mg} \mathrm{m}^{-3}$ & 1.41 & 1.5 & 1.46 & 1.51 \\
\hline $\mathrm{pH}(1: 2.5)$ soil and water & & 7.97 & 8.09 & 7.98 & 8.01 \\
\hline EC soil paste extract & $\mathrm{dS} \mathrm{m}^{-1}$ & 1.32 & 1.23 & 1.37 & 1.25 \\
\hline OM & $\%$ & 1.38 & 1.23 & 1.39 & 1.25 \\
\hline \multicolumn{6}{|l|}{ Soluble cations } \\
\hline $\mathrm{Ca}$ & meq $L^{-1}$ & 6.4 & 6.01 & 6.13 & 6.0 \\
\hline $\mathbf{M g}$ & meq $L^{-1}$ & 3.2 & 2.6 & 3.23 & 2.51 \\
\hline $\mathrm{Na}$ & meq $L^{-1}$ & 5.1 & 4.89 & 5.29 & 5.0 \\
\hline $\mathbf{K}$ & meq L ${ }^{-1}$ & 0.81 & 0.8 & 0.84 & 0.8 \\
\hline \multicolumn{6}{|l|}{ Soluble anions } \\
\hline $\mathrm{HCO}_{3}$ & meq $L^{-1}$ & 4.31 & 5 & 4.32 & 5.14 \\
\hline $\mathrm{CO}_{3}$ & meq $L^{-1}$ & 0 & 0 & 0 & 0 \\
\hline Cl & meq $L^{-1}$ & 7.11 & 6.89 & 7.22 & 6.84 \\
\hline $\mathrm{SO}_{4}$ & meq $L^{-1}$ & 4.09 & 2.41 & 3.95 & 2.33 \\
\hline CEC & Cmole kg ${ }^{-1}$ & 46.12 & 45.01 & 47.1 & 45.12 \\
\hline \multicolumn{6}{|l|}{ Available nutrients } \\
\hline $\mathbf{N}$ & $\mathrm{mg} \mathrm{kg}^{-1}$ & 40 & 38 & 43 & 39 \\
\hline $\mathbf{P}$ & $\mathrm{mg} \mathrm{kg}^{-1}$ & 6 & 5.01 & 6.01 & 4.98 \\
\hline K & mg kg- ${ }^{1}$ & 300 & 289 & 313 & 284 \\
\hline
\end{tabular}




\section{Analysis of soil and biochar}

The soils were characterized for their physical and chemical properties following standard laboratory procedures (Klute \& Dirksen 1986\& Page et al. 1982). Soil $\mathrm{pH}$ and electrical conductivity (EC) were measured in a saturated soil paste extract and biochar in a water (1:10 biochar: water ratio) using a pH/conductivity meter. Organic carbon was determined by sulphuric acid and dichromate oxidation according to (Walkley \& Black 1934). Soil organic carbon content of the biochar was determined by combustion method (Page et al. 1982). The cations and anions were determined in a saturated soil paste extract as described by (Rhoades 1954). The soil texture was determined using the international pipette method, as described by (Kim 1996). Cation exchange capacity (CEC) was determined by the (1 M NH $\mathrm{NHAC}_{4}$ at $\mathrm{pH}$ 7.0) method (Jackson 1974). Exchangeable $\mathrm{Na}$ and $\mathrm{K}$ were measured by the flame photometer (Rich 1965). Total nitrogen (N) was determined by the macro-Kjeldahl method (Page et al. 1982).

\section{Microbial biomass carbon}

Microbial biomass carbon (MBC) was determined by the fumigation-extraction technique. Ten grams of soil was fumigated with chloroform $\left(\mathrm{CHCl}_{3}\right)$ for 24 $h$ at $25^{\circ} \mathrm{C}$, and samples were extracted with $50 \mathrm{ml} 0.5 \mathrm{M} \mathrm{K}_{2} \mathrm{SO}_{4}$ for $30 \mathrm{~min}$ on a

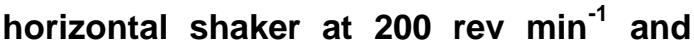
filtered through paper (Whatman No. 42). Similarly, $10 \mathrm{~g}$ soil was extracted for nonfumigation at the same time (Brookes et al. 1985). Soil organic carbon (SOC) in the extracts was measured by the titration method. Then MBC was calculated as: Microbial biomass $\mathrm{C}=$ ( $\left.C_{\text {fumigated }}-C_{\text {unfumigated }}\right) \times 2.64$.

\section{Phosphorus fractionation}

Soil samples after harvesting of wheat 2015-2016 season were collected from each plot at a depth $0-30 \mathrm{~cm}$ and 30-60 $\mathrm{cm}$. the fractionation of $P$ in the soil was carried out the following the sequential extraction, analysis according to (Hedley et al. 1982) procedure and modified by Chen et al. 2000. The extraction was: exchangeable phosphorus extracted by $0.5 \mathrm{~g}$ air dried soil with $30 \mathrm{ml} \mathrm{NH}_{4} \mathrm{Cl}$ (1M) in centrifuge tubes, labile phosphorus by $30 \mathrm{ml}$ of $0.5 \mathrm{M} \mathrm{NaHCO}_{3}$ (pH 8.5), Al and $\mathrm{Fe}$ phosphates by $0.1 \mathrm{M} \mathrm{NaOHi}, \mathrm{Ca}-$ phosphate by $1 \mathrm{M} \mathrm{HCl}$, unlabeled $P$ by 0.1 $\mathrm{M} \mathrm{NaOHii}$. All centrifuge tubes used in this process were shaken for $16 \mathrm{~h}$ at room temperature, and filtered with Whatman No. 42. The organic $P$ (Po) in $\mathrm{NaHCO}_{3}, \mathrm{NaOHi}$ and $\mathrm{NaOHii}$ extracts was obtained by digesting $5 \mathrm{ml}$ of each extractable with $\mathrm{H}_{2} \mathrm{SO}_{4}$ and $\mathrm{H}_{2} \mathrm{O}_{2}$ and calculation as the ( $\mathrm{Pt}$ mince $\mathrm{Pi}$ ) of respective extracts. Residual $P$ in soil samples was measured after digestion with $\left(\mathrm{HNO}_{3}-\mathrm{HClO}_{4}\right)$. The $\mathrm{P}$ concentration in all extracts analyzed calorimetrically with the molybdate-blue method at $\mathbf{8 8 0}$ nm (Murphy \& Riley 1962).

$$
\begin{aligned}
& \mathrm{P}_{\mathrm{T}}= \mathrm{NH}_{4} \mathrm{Cl}+\mathrm{NaHCO}_{3}+\mathrm{NaOHi}+\mathrm{HCl}+\mathrm{NaOHii} \\
&+ \text { residual } \\
& \mathrm{P}_{\mathrm{o}}= \text { NaHCO } \\
& \text { residual } \\
& \mathrm{P}_{\mathrm{o}}+\mathrm{NaOHi}-\mathrm{P}_{\mathrm{o}}+\mathrm{NaOHii}-\mathrm{P}_{\mathrm{o}}+ \\
& \mathrm{P}_{\mathrm{i}}= \mathrm{NH}_{4} \mathrm{Cl}+\mathrm{NaHCO}_{3}-\mathrm{P}_{\mathrm{i}}+\mathrm{NaOHi}-\mathrm{P}_{\mathrm{i}}+\mathrm{HCl}+ \\
& \mathrm{NaOHi}-\mathrm{P}_{\mathrm{i}}
\end{aligned}
$$

\section{Statistical analysis}

Values of treatments were analyzed statistically using SAS software (1996). Compare the differences between all values of treatments used Duncan's multiple range tests statistical significance level of $\mathrm{P}<0.05$ was used.

\section{RESULTS AND DISCUSSION}

Effect of biochar and different amounts of inorganic $P$ on grain yield of wheat and microbial biomass carbon

\section{Grain yield of wheat}

It has been observed that fertilization 
of $\mathbf{P}$ or combinations between $\mathbf{P}$ fertilizer levels and biochar significantly increased grain yield of wheat crops in the growing 2015 and 2016 seasons (Fig. 1). Biochar with $150 \%$ P treatment gave the highest significant increase in the grain yield of wheat compared to other treatments. The interaction between biochar and phosphorus led to above $\mathbf{3 0} \%$ increase in grain yield compared with the use of the $P$ mineral fertilizer alone. This indicates the ability of the mixed addition of biochar and fertilizer $P$ to maintain soil fertility through an increase in the labile $P$ fraction. Similarly, increases in grain yield of wheat plants with $P$ fertilization and biochar are probably due to improve in soil physical properties and organic matter (Mahmoud et al. 2017). And also, with the addition of biochar, yield increase of plants can be related to soil quality improvement Azeez et al.
2010,Demir et al. 2010), enhance nutrient supply to the plants (Gaskin et al. 2010), and increase microbial biomass and activity in soil (Gunes et al. 2014). Grain yield of wheat in the soil amended biochar and $P$ did not increase significantly between the application at $100 \%$ and $150 \%$ P. The increase in available phosphorus has increased grain yield. Biochar has been found to alter $P$ availability through its electrostatic repulsion and ion competition (Cui 2011). (Atkinson et al. 2010) reviewed several mechanisms which can enhance availability and plant uptake of $P$, which led to increase crop productivity after biochar addition to soil. It acts as a source of soluble $P$ salts and exchangeable $P$ forms; soil avoids $P$ precipitation by modifying $\mathrm{pH}$ or enhances microbial activity leading to changes in $P$ availability.

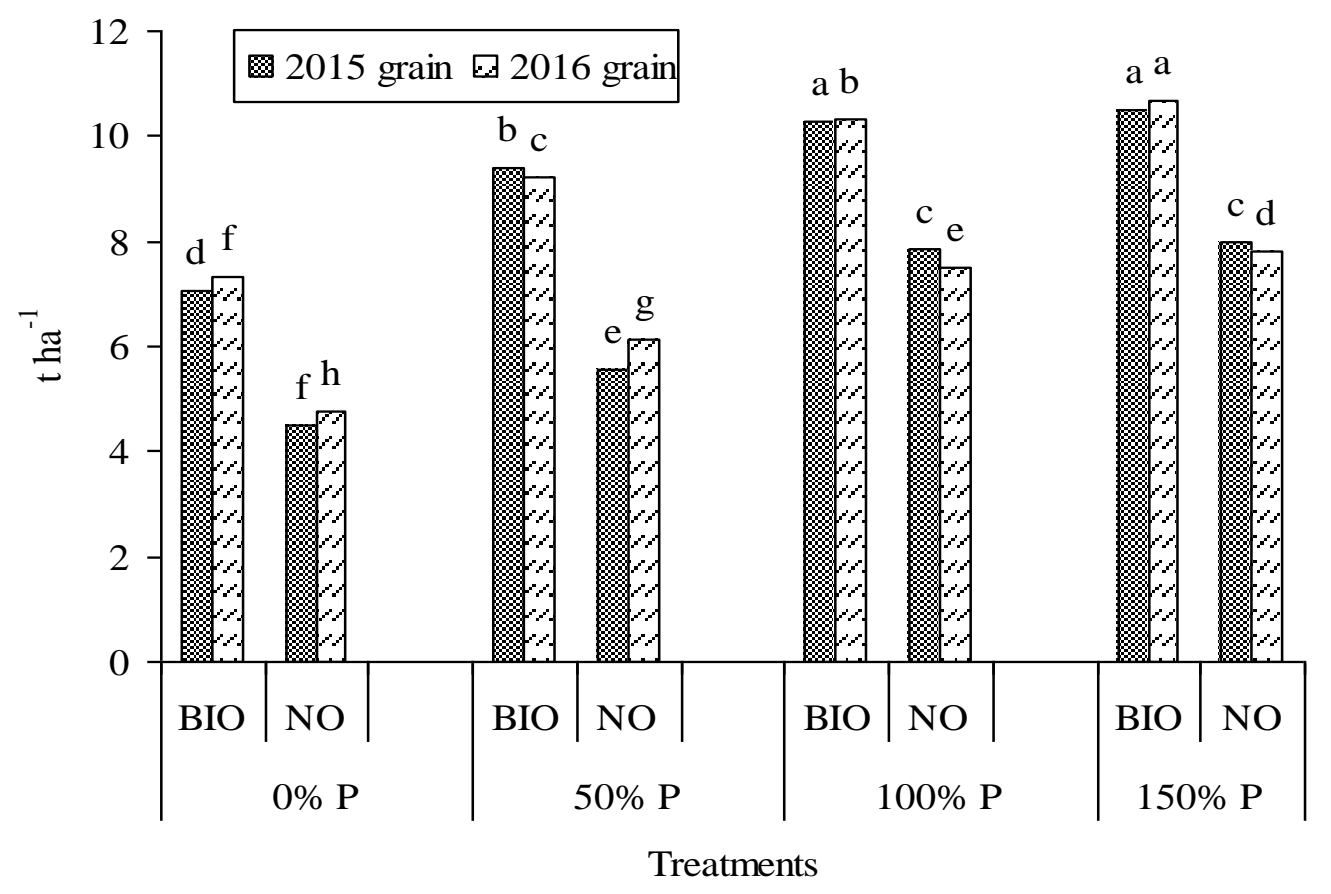

Bio: biochar at 10t/ha. No: without biochar

Figure 1. Effect of biochar and different amounts of inorganic $P$ on grain yield of wheat crops in the growing 2015 and 2016 seasons. 


\section{Soil microbial biomass carbon}

Soil microbial biomass carbon (MBC) in the soil is a good indicator of biological activity of soil, soil quality, and it's generally positively correlated with the soil organic matter (SOM) content and soil $\mathrm{pH}$. Thus, the changes in MBC may lead to changes in organic matter (OM) decomposition and nutrient cycling (Dick et al. 1996 and Caldwell 2005). In general, soil MBC was significantly increased with the application rate of the phosphorus and biochar (Fig 2). The highest MBC was recorded in soil amended with $150 \% \mathrm{P}$ amended biochar (209.60 $\left.\mathrm{g} \mathrm{kg}^{-1}\right)$. P application, microbial biomass in $0-30 \mathrm{~cm}$ soil depth increased by $52 \%, 49 \%$, and $46 \%$ when fertilizer $P$ rates were 50,100 , and $150 \% P$, respectively, (Brendecke et al. 1993) found similar results, noting that the addition of organic carbon and nutrients through sewage sludge increased the population of microbes in the soil, which in turn stimulated enzymatic activity in the soil. The obtained results point out The increase in the MBC is correlated with soil organic matter $\left(R^{2}=0.94, p<0.05\right.$, Fig. 3). Microbial biomass increased with biochar addition is due to the presence of labile $C$ fractions, un-pyrolysed feedstocks and biochar have been surfaces supplying nutrients for the microbes (Bruun et al. 2011; Zimmerman 2011,; Luo et al. 2013).The higher in P, C and other nutrients with the phosphorus and biochar amended plots could contribute to increase soil microbial biomass. The co-application of biochar with inorganic $P$ produced up to $\mathbf{1 . 5}$ fold more microbial biomass $C$ than either biochar or inorganic $P$ applied alone. (Gichangi et al. 2009) observed the similar results and reported that microbial biomass increased with the coapplication of inorganic $P$ with goat manure in small-holder farms in South Africa.

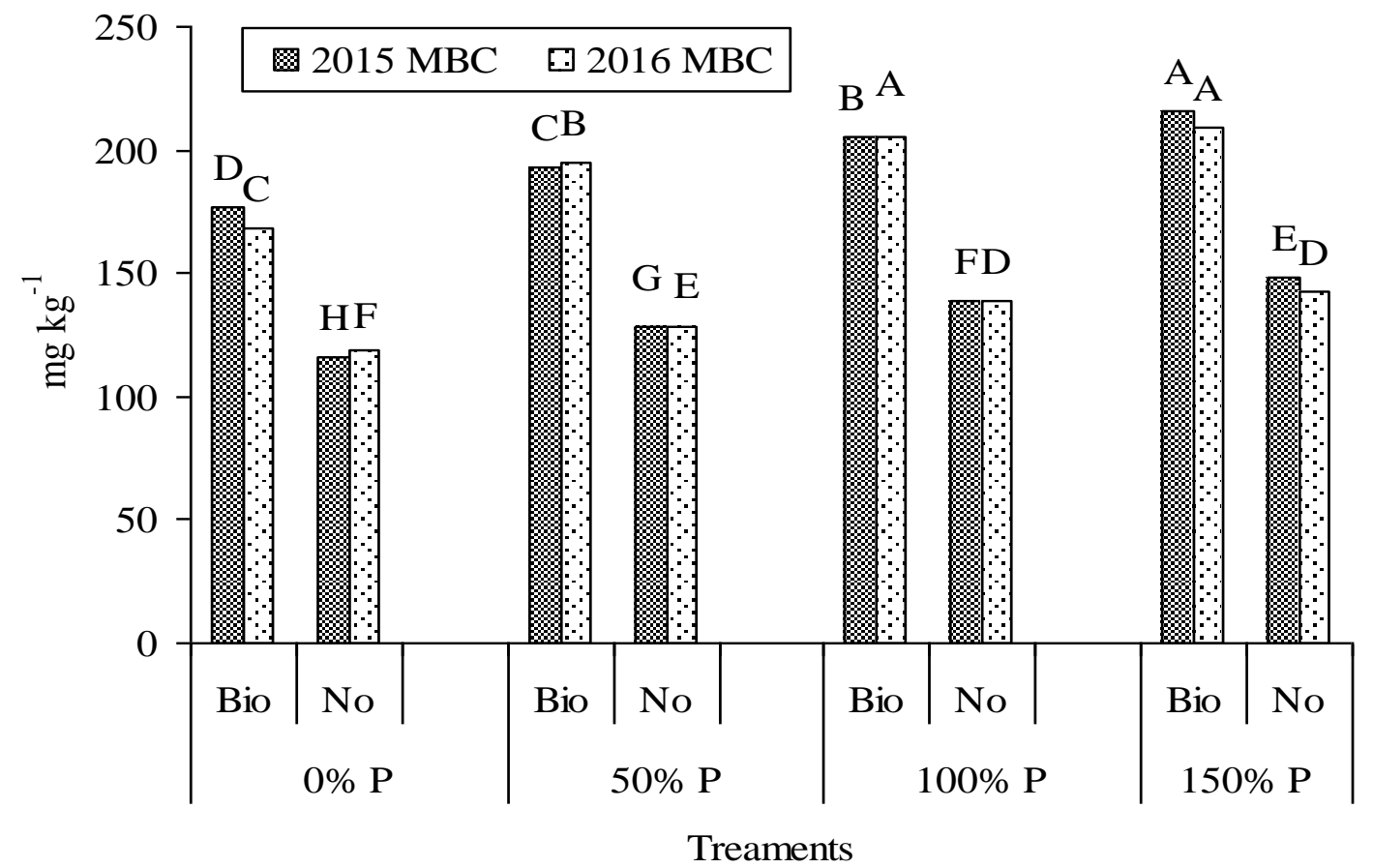

Figure 2. Effect of biochar and different amounts of inorganic $P$ on soil microbial biomass carbon (MBC) in the growing 2015 and 2016 seasons. 


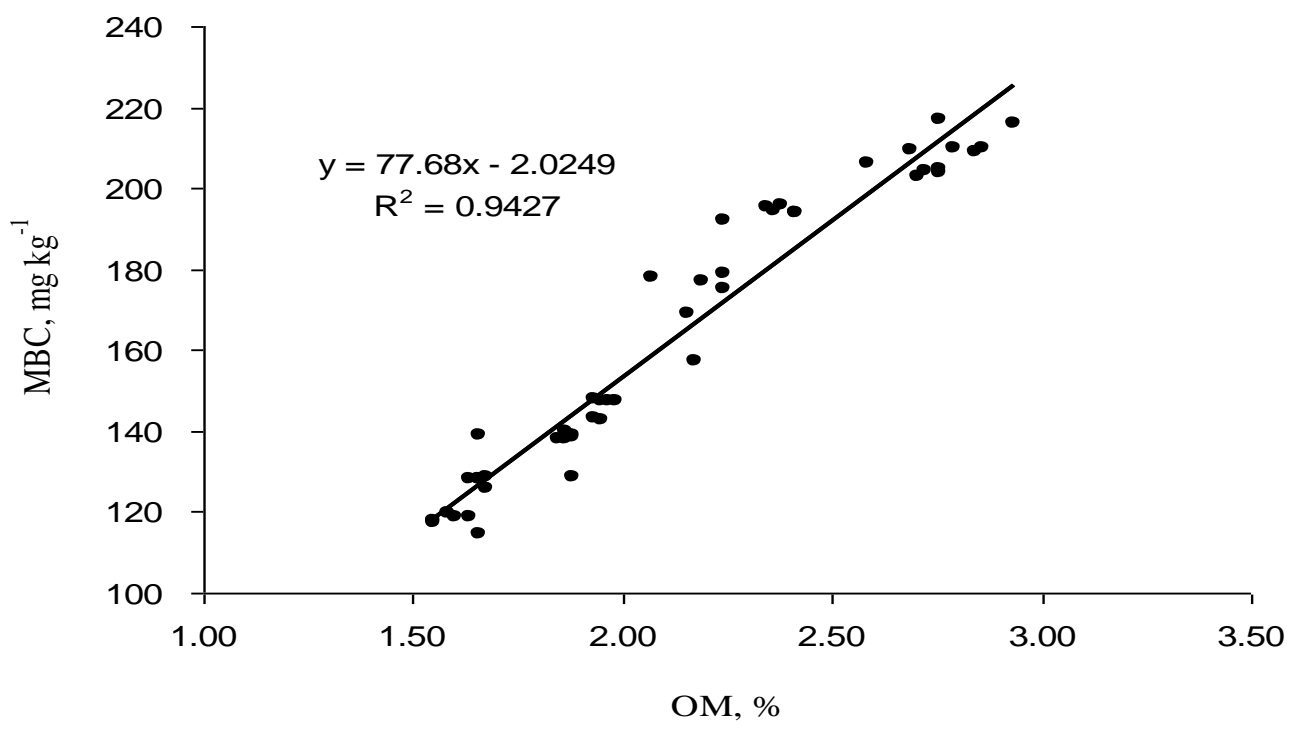

Figue 3. Relationship between soil organic matter (SOM) and microbial biomass carbon (MBC)

\section{Phosphorus fractionation}

$\mathrm{NH}_{4} \mathrm{Cl}-\mathrm{P}$ (exchangeable phosphorous) significantly increased in soil treated with $P$ fertilizers or in combination with biochar in both two depths (Table 3). $\mathrm{NH}_{4} \mathrm{Cl}$ fraction $\mathrm{P}$ increased with increasing $P$ rates in the plots treated with biochar or without biochar, The $\mathrm{NH}_{4} \mathrm{Cl}-\mathrm{P}$ in the soil amended biochar did not increase significantly between the application at $50 \% \mathrm{P}$ and $100 \% \mathrm{P}$ in $30-60$ depth. Fertilization of $\mathbf{P}$ increased significantly $\mathrm{NH}_{4} \mathrm{Cl}-\mathrm{P}$ in both depths. Similarly, (Amaizah et al. 2012) found that the content of water-soluble phosphorus increased with the soil treated with fertilization with mineral phosphorus as compared with the control. This increase is due to the accumulation of $P$ and was influenced by the saturation of free spaces for adsorption of $P$ in soil. The increase of $\mathrm{NH}_{4} \mathrm{Cl}-\mathrm{P}$ in the $30-60 \mathrm{~cm}$ depth was lower in the soil treated by biochars with the mineral phosphorus, which could be explained by movement of $P$ along the depth was very limited and slow due to its strong binding (Amaizah et al. 2012).

The $\mathrm{NaHCO}_{3}-\mathrm{P}$ labile fraction ranged between 24.95 and $40.65 \mathrm{mg} \mathrm{P} \mathrm{kg}^{-1}$, which is equivalent to $11.14 \%$ and $12.26 \%$ of total $P$ in the growing 2015 season (Table 3). Fertilization of $P$ increased significantly $\mathrm{NaHCO}_{3}-\mathrm{P}$ in both depths. Similar results were reported by (Sharpley \& Smith 1983). $\mathrm{NaHCO}_{3}-\mathrm{P}$ (labile phosphorus) did not increase significantly in the amended $P$ and biochar plots except $150 \% P$ in the $0-30$ $\mathrm{cm}$ depth and increased significantly in 30 - 60 depth. $\mathrm{NaHCO}_{3}-\mathrm{P}$ labile fraction was higher in the amended biochar plots at different $P$ rates than in the unamended biochar plots, except of $150 \% P$ in the un-amended biochar plots at 30-60 cm depth.

Phosphate bound to ( $\mathrm{Al}$ and $\mathrm{Fe}$ ) were higher in the soil amended biochar (ranged from 7.9 to $18.44 \mathrm{mg} \mathrm{P} \mathrm{kg}^{-1}$ ) than without biochar (ranged from 2.49 to $10.45 \mathrm{mg} \mathrm{P} \mathrm{kg}^{-1}$ ) at two depths (Table 3). Phosphate bound to (Al and $\mathrm{Fe}$ ) 


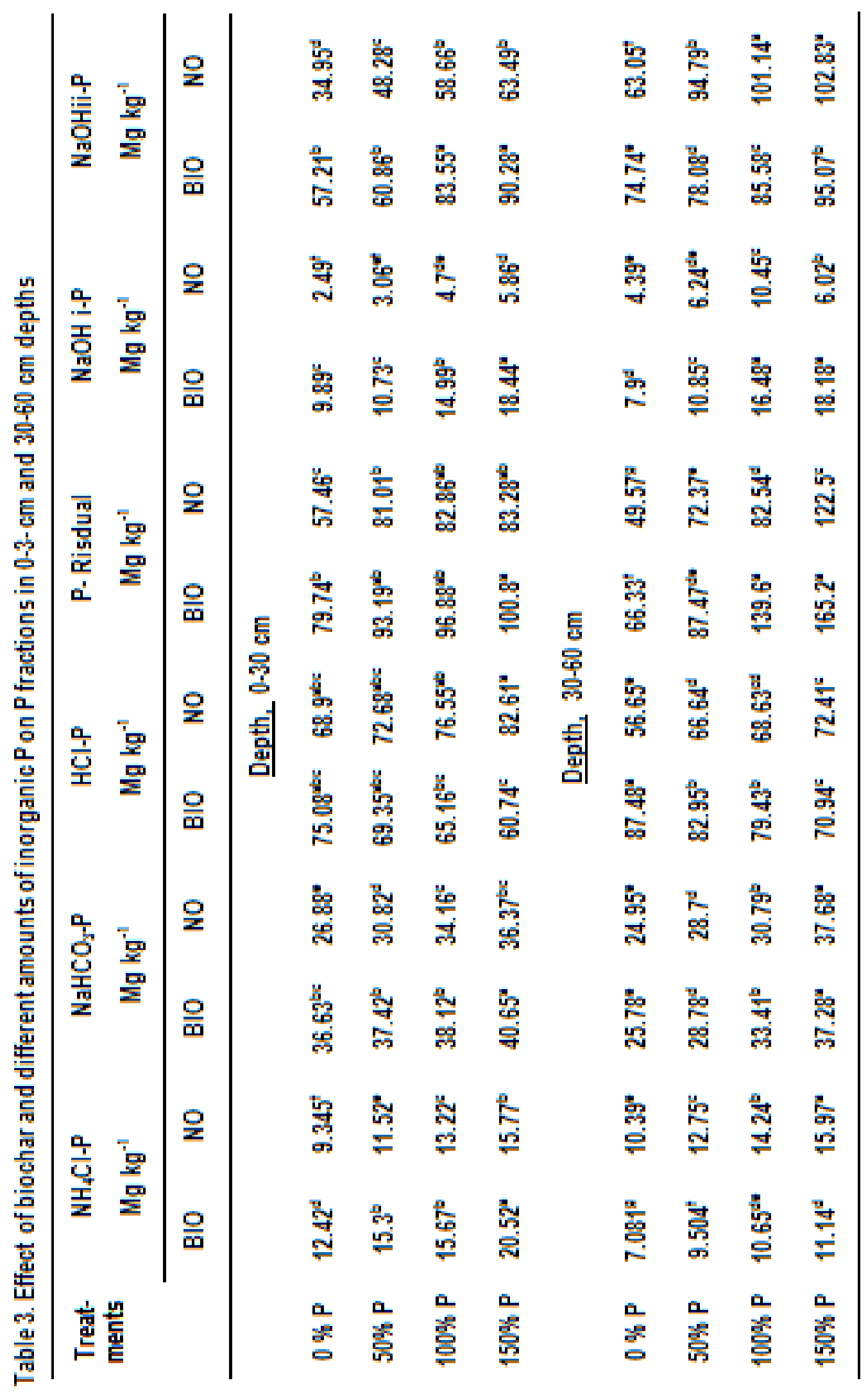


increased significantly with increasing $P$ rates in the soil amended biochar or without biochar except of $50 \% \mathrm{P}$ in $0-30$ cm depth. In alkaline soils, as in the present case, $P$ is fixed mainly by calcium, while in acidic mineral soils by aluminum and iron (Tunesi 1999). Phosphate bound to (Al and $\mathrm{Fe}$ ) represented a very small fraction (about 1.25 to $4.24 \%$ without biochar but 3.6 to $5.56 \%$ with biochar) of total P. The hydroxide $\mathrm{P}(\mathrm{Pi}$ and $\mathrm{Po}$ ) fraction is considered a moderately labile $\mathbf{P}$ ( $P i$ and Po) pools that are bound with amorphous and some crystalline $\mathrm{Al}$ and $\mathrm{Fe}$ (Tiessen \& Moir 2007), with low availability to plants (Cui 2011).

The $\mathrm{HCl}$ extractable fraction ranged between 60.74 and $87.48 \mathrm{mg} \mathrm{P} \mathrm{kg}^{-1}$, which are equivalent to 18.32 and $32.48 \%$ of total $\mathrm{P}$ in the amended biochar plots (Table 3). $\mathrm{HCl}-\mathrm{P}$ decreased nonsignificantly in soil treated with the biochar and $P$ in $\mathbf{0 - 3 0} \mathrm{cm}$ depth. In the non-biochar treatments, the $\mathrm{HCl}$ extractable increased with increasing $P$ rates in the two depths. Similarly, increases in HC1- $P$ with inorganic $P$ fertilization are most likely due to the effect of exchangeable $\mathrm{Ca}^{2+}$ or $\mathrm{Mg}^{2+}$ which can significantly affect the absorption of $\mathbf{P}$ in tropical soils (Smillie et al. 1987) including savanna soils (Agbenin 2003). The content of $\mathrm{HCl}-\mathrm{P}$ is more than those observed by (Adhami et al. 2007) in calcareous soils of Iran. The difference is due to a type of soils in this study.

NaOHii extractable (unlabeled P) increased significantly with the soil treated by phosphorus and biochar or without biochar in the two depths (Table 3). Unlabeled $\mathbf{P}$ concentrations were increased by $19.36 \%$ and $32.52 \%$ under $50 \% \mathrm{P}$ in the no-biochar plots at $0-30 \mathrm{~cm}$ and $30-60 \mathrm{~cm}$ depths, respectively. (Motavalli \& Miles 2002) observed the similar results and reported that phosphorus in the $\mathrm{NaOH}$ fractions increased significantly above the control with $\mathbf{P}$ additions and manure.

Residual P ranged from 66.33to $\mathbf{1 6 5 . 2}$ $\mathrm{mg} \mathrm{kg}^{-1}$ in amended soil with biochar and fertilizer P (Table 3), and accounted for $24.63 \%$ to $40.51 \%$ of the total P. Residual $P$ increased over the control when the biochar with fertilizer $P$ at $150 \%$ were applied in both depths. $P$ application, residual $P$ at $\mathbf{0}-30 \mathrm{~cm}$ soil depth increased by $40.9 \%, 44.2 \%$, and $44.9 \%$ when fertilizer $P$ rates were 50,100 , and $150 \% P$, respectively.

\section{Total $\mathbf{P}$}

In the amended biochar and $P$ plots, total $P$ ranged from 269.3 to $407.8 \mathrm{mg} \mathrm{kg}^{-1}$ (Fig. 4). Biochar contributed about $35 \%$ and $20 \% P_{t}$ in the surface and subsurface layers, respectively. Most of the total $\mathbf{P}$ in amended biochar was about $28.54 \%$ and $28.25 \%$ in organic forms and inorganic, respectively. (Hong \& Lu 2018) observed the similar and found that that the total P content increased with biochar addition.

The contents of $P_{t}$ fractions increased after fertilizer $P$ applications as shown in Fig (4), there is significant differences were found between fertilizer $P$ levels and treatment compared to control. (Blackwell et al. 2010) studied the effect of biochar and fertilizer in several dry land cropping soils of Australia; they found reduced $P$ fertilizer requirements in biochar addition because biochar itself as source of $P$ a similar manner to the present study.

\section{Inorganic phosphorus}

The soil inorganic $\mathbf{P}$ constituted between $39-59 \%$ of the $P_{t}$ in all treatments in both depths. Fertilization of $P$ increased significantly inorganic- $P$ in both depths (Fig. 4). Inorganic-P increased with the increasing $P$ rates. These results are in are agreed with 
(Sharpley \& Smith 1983), who found that inorganic $\mathbf{P}$ increased with $\mathbf{P}$ fertilization applications in cultivated soil. The inorganic $P$ fractions were increased significantly when the biochar was combined with fertilizer $\mathbf{P}$. This indicates the ability of the mixed addition of biochar and fertilizer $P$ to maintain soil fertility through an increase in the labile $P$ fraction (Zhang \& MacKenzie 1997). According to (Tisdale \& Nelson 1990), concentrated $P$ solution may cause the release of reactive cations such as $\mathrm{Ca}^{2+}$,
$\mathrm{Mg}^{2+}, \mathrm{Fe}^{3+}$ and $\mathrm{Al}^{3+}$ the $\mathrm{P}$ in the solution reacts with these cations forming active inorganic $P$ fractions with varying solubility. The observed relatively lower soil inorganic $P$ at $100 \%$ and $150 \% P$ application may have resulted from higher $\mathbf{P}$ concentration in soil solution leading to higher sorption and formation of more complexes with the dissolved cations (Abekoe \& Sahrawat 2007). (Schmidt et al. 2011) found that all for fraction increased by phosphorus fertilization.

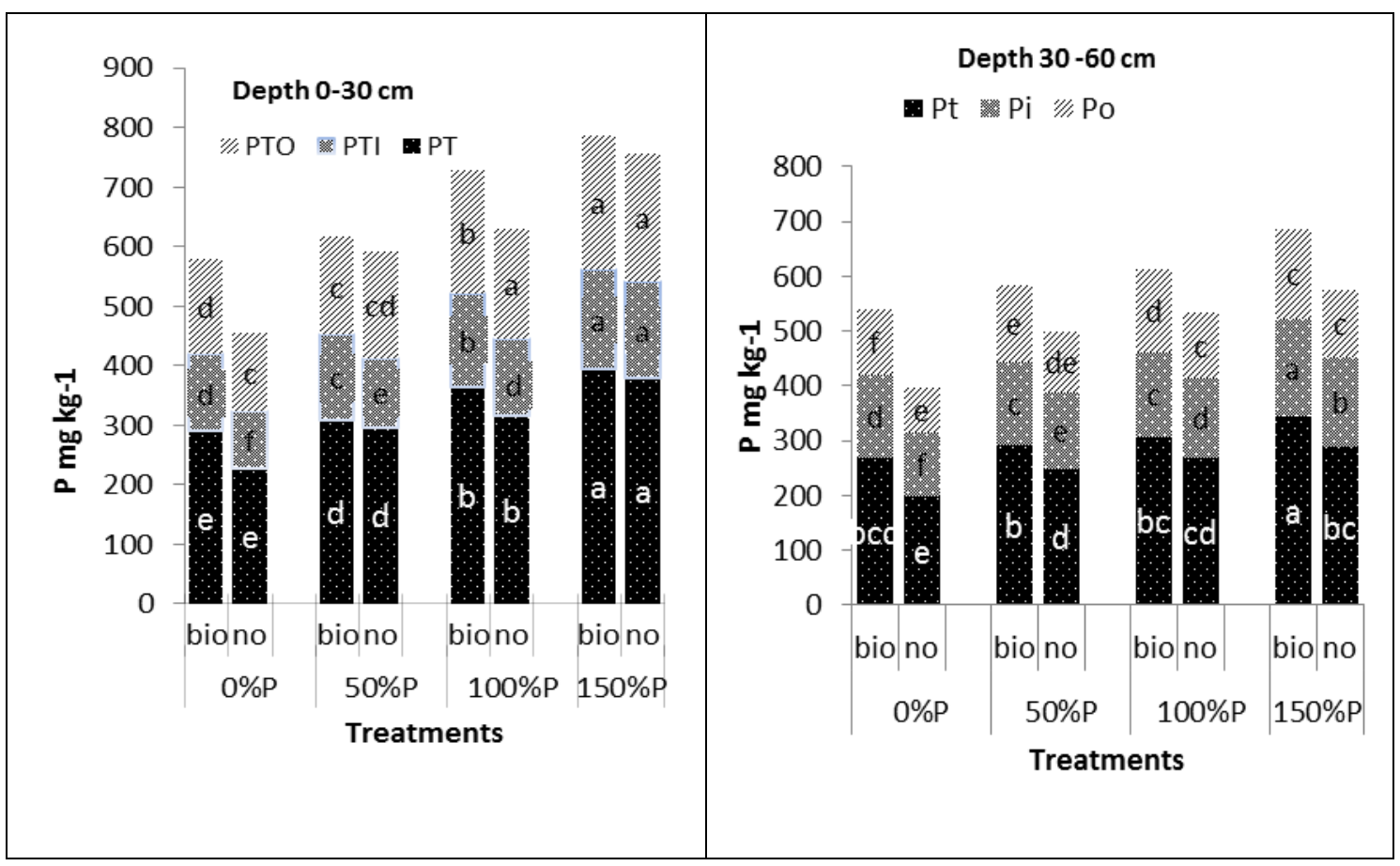

Figure 4. Effect of biochar and different amounts of inorganic $P$ on organic and inorganic $P$ fractions in 0-3- $\mathrm{cm}$ and $30-60 \mathrm{~cm}$ depths.

\section{Organic phosphorus}

Soil Po contents ranged from 120.9 to $165.1 \mathrm{mg} \mathrm{kg}^{-1}$ in the amended biochar and $P$ plots at $0-30 \mathrm{~cm}$ depth (Fig. 4). Biochar, along with different $P$ fertilizer applications increased the contents of $P_{o}$ fraction, there is significant differences were found between fertilizer $P$ levels and biochar compared to control. Biochar contributed about $48 \%$ and $21 \% P_{\circ}$ in the surface and sub-surface layers, respectively. Organic-P increased with the increasing $\mathbf{P}$ rates. These results are in are agreeing with (Velásquez et al. 2016), who found that organic $P$ increased with $P$ fertilization applications in arable soils. The organic $P$ fractions were increased significantly when the biochar was combined with fertilizer $P$. Farrell et al. 2013 observed the similar results and reported that organic $P$ fractions increased significantly with biochar combined with fertilizer $P$. 


\section{Conclusions}

The results demonstrated that the effects of the co-application of $P$ fertilizers and a biochar contributed to improving wheat yield, labile $P$ fraction and soil quality in alkaline soil. Coapplication of $\mathbf{P}$ fertilizers with biochar significantly increased soil microbial biomass carbon, grain yield of wheat crops and organic and inorganic phosphorus compared to biochar or $\mathbf{P}$ fertilizers alone application. labile $P$ fraction ranged between 24.95 and $\mathbf{4 0 . 6 5}$ $\mathrm{mg} \mathrm{P} \mathrm{kg}{ }^{-1}$, which is equivalent to $11.14 \%$ and $12.26 \%$ of total $P$. increases in the grain yield of wheat crops and microbial biomass carbon in the soil treated by combinations between $P$ mineral and biochar are important for sustainable good soil properties and soil productivity. Therefore, combinations between $P$ mineral and biochar can be used to improve soil productivity, sequester $C$ and soil quality.

\section{Acknowledgements}

The author would like to thank the Laboratory of Soil and Water Sciences, Agriculture faculty, Tanta University, Egypt, for their assistance during this work.

\section{REFERENCES}

Abekoe, M.K. and K.L. Sahrawat (2007). Long-Term Cropping Effect on Phosphorus Fractions in an Ultisol of the Humid Forest Zone in West Africa. Communications in Soil Science and Plant Analysis 34: 427-437.

Adhami, E., H.R. Memarian and F. Rassaei (2007). Relationship between phosphorus fractions and properties of highly calcareous soils. Soil Research 45: 255-261.

Agbenin, J.O. (2003). Extractable iron and aluminum effects on phosphate sorption in a savanna alfisol. Soil Science Society of America Journal 67: 589-595.
Amaizah, N., D. Cakmak and E. Saljnikov (2012). Fractionation of soil phosphorus in a long-term phosphate fertilization. Journal of the Serbian Chemical Society 77: 971-981.

Atkinson, C.J., J.D. Fitzgerald and N.A. Hipps (2010). Potential mechanisms for achieving agricultural benefits from biochar application to temperate soils: a review. Plant and soil 337: 118.

Azeez, J.O., W. Van Averbeke and A.O. Okorogbona (2010). Differential responses in yield of pumpkin (Cucurbita maxima L.) and nightshade (Solanum retroflexum Dun.) to the application of three animal manures. Bioresour Technol 101: 2499-2505.

Blackwell, M.S.A., P.C. Brookes and N. de la Fuente-Martinez (2010). Chapter 1 Phosphorus Solubilization and Potential Transfer to Surface Waters from the Soil Microbial Biomass Following Drying-Rewetting and Freezing-Thawing. In: Sparks DL (ed) Advances in Agronomy, pp 1-35. Academic Press.

Brendecke, J.W., R.D. Axelson and I.L. Pepper (1993). Soil microbial activity as an indicator of soil fertility: longterm effects of municipal sewage sludge on an arid soil. Soil Biology and Biochemistry 25: 751-758.

Brookes, P., A. Landman, G. Pruden and D. Jenkinson (1985). Chloroform fumigation and the release of soil nitrogen: a rapid direct extraction method to measure microbial biomass nitrogen in soil. Soil biology and biochemistry 17: 837-842.

Bruun, E.W., H. Hauggaard-Nielsen and N. Ibrahim (2011). Influence of fast pyrolysis temperature on biochar labile fraction and short-term carbon loss in a loamy soil. Biomass and Bioenergy 35: 1182-1189.

Caldwell BA 2005: Enzyme activities as a component of soil biodiversity: A review. Pedobiologia 49: 637-644. 
CAPMAS (2014). Future of Energy in Egypt. Cairo, Egypt: Central Agency for Public Mobilization and Statistics (CAPMAS).

Chathurika, J.S., D. Kumaragamage and F. Zvomuya (2016). Woodchip biochar with or without synthetic fertilizers affects soil properties and available phosphorus in two alkaline, Chernozemic soils. Canadian journal of soil science 96: 472-484.

Chen, C.R., L.M. Condron, M.R. Davis and R.R. Sherlock (2000). Plant and Soil 220: 151-163.

Chintala, R., T.E. Schumacher and L.M. McDonald (2014). Phosphorus Sorption and Availability from Biochars and Soil/Biochar Mixtures. CLEAN - Soil, Air, Water 42: 626-634.

Condron, L.M. and S. Newman (2011). Revisiting the fundamentals of phosphorus fractionation of sediments and soils. Journal of Soils and Sediments 11: 830-840.

Cui, H-J, MK Wang, M-L Fu and E. Ci (2011). Enhancing phosphorus availability in phosphorus-fertilized zones by reducing phosphate adsorbed on ferrihydrite using rice straw-derived biochar. Journal of Soils and Sediments 11: 1135-114

Demir, K., O. Sahin, Y. Kadioglu, D. Pilbeam and A. Gunes (2010). Essential and non-essential element composition of tomato plants fertilized with poultry manure. Scientia Horticulturae 127: 16-2

Dick, R.P., D.P. Breakwell and R.F. Turco (1996). Soil enzyme activities and biodiversity measurements as integrative microbiological indicators. Methods for assessing soil quality, 247-27

Enders, A., K. Hanley, T. Whitman, S. Joseph and J. Lehmann (2012). Characterization of biochars to evaluate recalcitrance and agronomic performance. Bioresour Technol 114, 644-653.
Farrell, M., L.M. Macdonald, G. Butler, I. Chirino-Valle and L.M. Condron (2013). Biochar and fertiliser applications influence phosphorus fractionation and wheat yield. Biology and Fertility of Soils 50: 169-178.

Gad, A-A and R. Ali (2011). Creation of GIS digital land resources database of the Nile delta, Egypt, for optimal soil management. Procedia-Social and Behavioral Sciences 19: 641-650.

Gaskin, J.W., R.A. Speir and K. Harris (2010). Effect of Peanut Hull and Pine Chip Biochar on Soil Nutrients, Corn Nutrient Status, and Yield. Agronomy Journal 102: 623.

Gichangi, E.M., P.N.S. Mnkeni and P.C. Brookes (2009). Effects of goat manure and inorganic phosphate addition on soil inorganic and microbial biomass phosphorus fractions under laboratory incubation conditions. Soil Science and Plant Nutrition 55: 764-771.

Gunes, A., A. Inal and M.B. Taskin (2014). Effect of phosphorus-enriched biochar and poultry manure on growth and mineral composition of lettuce (Lactuca sativaL.cv.) grown in alkaline soil. Soil Use and Management, 30(2): 182-188.

Hedley, M.J., J. Stewart and B. Chauhan (1982). Changes in inorganic and organic soil phosphorus fractions induced by cultivation practices and by laboratory incubations 1 . Soil Science Society of America Journal 46: $970-976$

Holford, I. (1997).: Soil phosphorus: its measurement, and its uptake by plants. Soil Research 35: 227-240.

Hong, C. and S. Lu (2018). Does biochar affect the availability and chemical fractionation of phosphate in soils? Environ Sci Pollut Res Int.

Jackson, D.N. (1974). Personality research form manual, research psychologists press. 
Jones, D.L., J. Rousk, G. Edwards-Jones, T.H. DeLuca and D.V. Murphy (2012). Biochar-mediated changes in soil quality and plant growth in a three year field trial. Soil Biology and Biochemistry 45: 113-124.

Kim, Y., I. Petrov, J. Greene and S. Rossnagel (1996). Development of 111 textures in Al films grown on SiO2/Si (001) by ultrahigh-vacuum primary-ion deposition', Journal of Vacuum Science \& Technology A: Vacuum, Surfaces, and Films 346-351.

Klute, A. and C. Dirksen (1986). Hydraulic conductivity and diffusivity: Laboratory methods. Methods of soil analysis: part 1-physical and mineralogical methods, 687-734.

Kumari, K.G.I.D., P. Moldrup, M. Paradelo and L.W. de Jonge (2014). Phenanthrene Sorption on BiocharAmended Soils: Application Rate, Aging, and Physicochemical Properties of Soil. Water, Air, \& Soil Pollution 225.

Laird, D.A., P. Fleming, D.D. Davis, R. Horton, B. Wang and D.L. Karlen (2010). Impact of biochar amendments on the quality of a typical Midwestern agricultural soil. Geoderma 158: 443449.

Luo, Y., M. Durenkamp, M. De Nobili, Q. Lin, B.J. Devonshire and P.C. Brookes (2013). Microbial biomass growth, following incorporation of biochars produced at $350{ }^{\circ} \mathrm{C}$ or $700^{\circ} \mathrm{C}$, in a silty-clay loam soil of high and low $\mathrm{pH}$. Soil Biology and Biochemistry 57: 513-523.

Mahmoud, E., T. El-Beshbeshy, N.A. ElKader, R. El Shal and N. Khalafallah (2017). Bio Char Impacts on Physical Properties and Wheat Yield of Salt Affected Soils International Journal of Research and Science publication, 2(1): 1-10.

Mohamed, S., A. Smouni, M. Neyra, D. Kharchaf and A. Filali-Maltouf (2000). Phenotypic characteristics of root- nodulating bacteria isolated from Acacia spp. grown in Libya. Plant and Soil 224: 171-183.

Motavalli, P.P. and R.J. Miles (2002). Inorganic and organic soil phosphorus fractions after long-term animal manure and fertilizer applications. Better Crops 86, 20-23.

Murphy, J. and J.P. Riley (1962). A modified single solution method for the determination of phosphate in natural waters. Analytica chimica acta 27: 31-36.

Novak, J.M., W.J. Busscher, D.L. Laird, M. Ahmedna, D.W. Watts and M.A. Niandou (2009). Impact of biochar amendment on fertility of a southeastern coastal plain soil. Soil science 174: 105-112.

Page, A., R. Miller and D. Keeney (1982). Methods of soil analysis. Part 2. Chemical and microbiological properties. American Society of Agronomy. Soil Science Society of America.

Rhoades, R. (1954). Diagnosis and improvement of saline and alkali soils. USDA Agriculture Handbook.

Rich, C. (1965). Elemental analysis by flame photometry. Methods of Soil Analysis. Part 2. Chemical and Microbiological Properties: 849-86

Schmidt, Michael WI Torn, Margaret S Abiven, Samuel Dittmar, Thorsten Guggenberger, Georg Janssens, Ivan A Kleber, Markus Kögel-Knabner, Ingrid Lehmann, Johannes Manning, David AC : Persistence of soil organic matter as an ecosystem property. Nature 478- 479.

Sharpley, A.N., S.J. Smith and L.W. Reed (1983). Selected properties of paired virgin and cultivated soils from major land resource areas, Agricultural Experiment Station, Division of Agriculture, Oklahoma State University.

Silber, A., I. Levkovitch and E. Graber (2010). pH-dependent mineral release 
and surface properties of cornstraw biochar: agronomic implications. Environmental science \& technology 44: 9318-9323.

Smillie, G., D. Curtin and J. Syers (1987). Influence of Exchangeable Calcium on Phosphate Retention by Weakly Acid Soils 1. Soil Science Society of America Journal 51: 1169-117

Solomon, D. and N. Lehman (2000). Loss of phosphorus from soil in semi arid northern Tanzania as a result of cropping: evidence from sequential extraction and 31P-NMR spectroscopy. European Journal of Soil Science 51: 699-708.

Tiessen, H. and J. Moir (2007). Characterization of available $P$ by sequential extraction, in Carter, M. R., Gregorich, E. G. (eds.): Soil Sampling and Methods of Analysis. CRC Press, Boca Raton FL, USA, pp. 293-306

Tisdale, S. and W. Nelson (1990). Soil fertility and effect of magnesium sources on the yield and chemical composition of crops. Michigan Agric. Experimental Sta. Bull Press, Michigan American 1990: 29-31.

Tunesi, S., V. Poggi and C. Gessa (1999). Phosphate adsorption and precipitation in calcareous soils: the role of calcium ions in solution and carbonate minerals. Nutrient Cycling in Agroecosystems 53: 219-227.

Turner, B.L., B.J. Cade-Menun, L.M. Condron and S. Newman (2005). Extraction of soil organic phosphorus. Talanta 66: 294-306.
Velásquez, G., M. Calabi-Floody and P. Poblete-Grant (2016). Fertilizer effects on phosphorus fractions and organic matter in Andisols. Journal of soil science and plant nutrition 16: 294309.

Walkley, A. and I.A. Black (1934). An examination of the Degtjareff method for determining soil organic matter, and a proposed modification of the chromic acid titration method. Soil science 37: 29-38.

Widowati, W. and A. Asnah (2014). Biochar Can Enhance Potassium Fertilization Efficiency and Economic Feasibility of Maize Cultivation. Journal of Agricultural Science 6.

Woolf, D., J.E. Amonette, F.A. StreetPerrott, J. Lehmann and S. Joseph (2010). Sustainable biochar to mitigate global climate change. Nat Commun 1: 56.

Yuan, J.H., R.K. Xu and H. Zhang (2011). The forms of alkalis in the biochar produced from crop residues at different temperatures. Bioresour Technol 102: 3488-3497.

Zhang, T.Q. and A.F. MacKenzie (1997). Changes of phosphorous fractions under continuous corn production in a temperate clay soil, Plant and Soil 192: 133-139.

Zimmerman, A.R., B. Gao and M-Y Ahn (2011). Positive and negative carbon mineralization priming effects among a variety of biochar-amended soils. Soil Biology and Biochemistry 43: 1169-1179. 
تاثير اضافه البيوشار مع التسميد الفوسفاتي على مفصلات الفسفور محصول القمح و الكتله الميكروييه بالاراضي القلوية

عيسوي قاسم محمود(1) ، محمود ابراهيم ابو زيد(1) ، لمياء عبدالحليم عبد الرحمن(2) ،

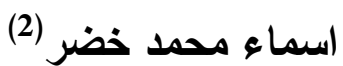

(1) قسم علوم الاراضي ، والمياه كليه الزراعه ، جامعه طنطا ، مصر.

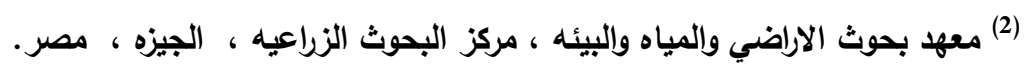

الملخص العربى

اجريت تجريه حقليه لاراسه تاثير البوشار و مستويات مختلفه من التسميد الفوسفاتي علي مفصلات الفسفور والكتل

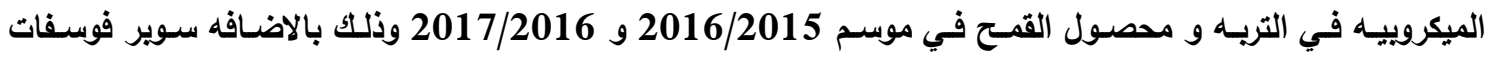

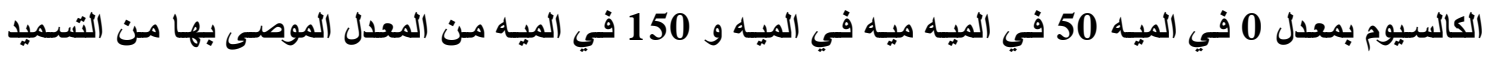

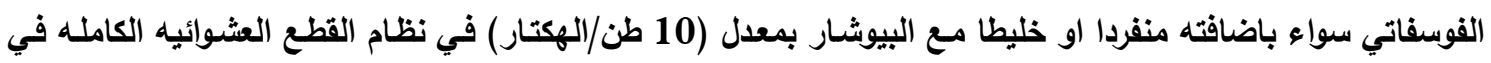

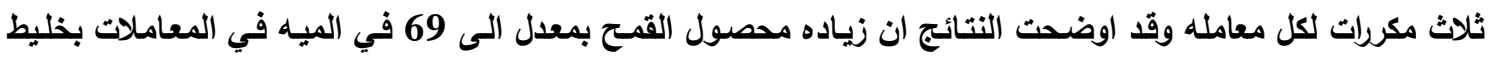

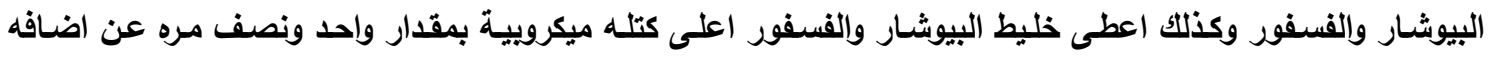

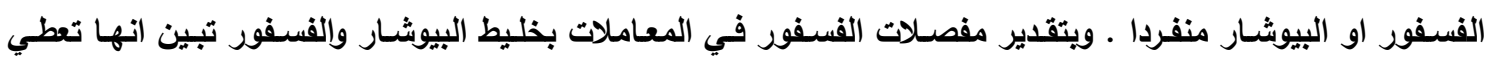
انخفاضا في الفسفور المرتبط بالهيدروكلوريك (HCL-P) بينما باقي المفصولات زادت بزياده التسميد الفوسفاتي اضافها

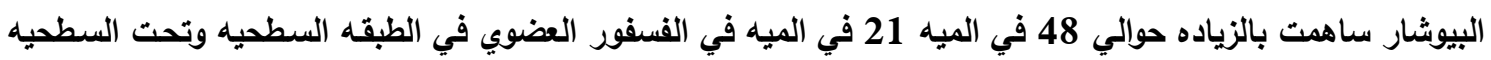

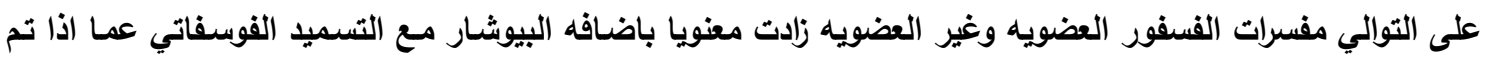
اضافه التسميد الفوسفاتي منفردا هذه النتائج تبين ان اضافه البيوشار مـع التسميد الفوسفاتي تمثل استراتيجيه افضل لتحسين جوده التربه في الاراضي القلويه .

\footnotetext{
أسماء السادة المحكمين

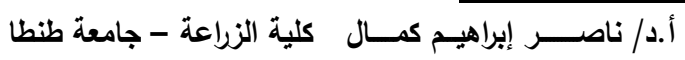

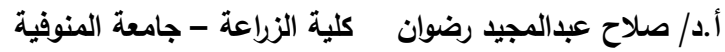


E. Mahmoud, et al., 